\title{
Corneal Endothelial Change after Phacoemulsification
}

\author{
Md. Abdus Salam Siddique ${ }^{1}$ \\ Received: August 1, 2015 Accepted: August 13, 2016 \\ doi: http://dx.doi.org/10.3329/jemc.v6i3.29679
}

\begin{abstract}
Background: Phacoemulsification is the modern method of sight restoring surgery for cataract and it is becoming popular day by day. We planned this study to find out any significant cell loss during this procedure leading to corneal endothelial decompression. Objective: To compare the preoperative and postoperative cell counts after phacoemulsification surgery. Materials and Methods: This prospective study was carried out at the National Institute of Ophthalmology and Hospital, Dhaka from July to September, 2008 to see the corneal endothelial change after phacoemulsification. A total of 60 cases with lental opacity, who underwent phacoemulsification surgery, were studied with specular microscope. The endothelial cell count was measured with specular microscope before and after cataract surgery. Postoperative cases were followed up to $1 \frac{1}{2}$ months after surgery. A single group of patients were studied and their preoperative and postoperative values were compared. The inclusion and exclusion criteria were maintained properly. Results: The mean preoperative endothelial cell count was $2745.35 \pm 395.27$ (SD) per $\mathrm{mm}^{2}$ which gradually decreased to $2545.23 \pm 348.83(\mathrm{SD})$ per $\mathrm{mm}^{2}$ at the end of $1 \frac{1}{2}$ months after surgery; mean cell loss was $200.12 \pm 46.44$ (7.29\%). Conclusion: This study reveals that a moderate loss of endothelial cell after phacoemulsification does not hamper the corneal transparency and visual function as depicted from visual acuity records in follow-up periods, provided the endothelium is healthy and the number is above the threshold limit.
\end{abstract}

Key words: Endothelial cell; Specular microscopy; Cataract; Phacoemulsification; Visco-elastic substances

J Enam Med Col 2016; 6(3): 134-139

\section{Introduction}

Phacoemulsification is the modern method of sight restoring surgery for cataract. Age related cataract is the major cause of blindness all over the world. So it has become the routine procedure for cataract surgery in the developed countries. Even in the developing countries like Bangladesh, it is becoming popular day by day. Number of phaco surgeons is also increasing as well. Phacoemulsification has some advantages over other methods of cataract surgery, viz., faster visual recovery, better uncorrected visual acuity (VA) and topical anesthesia may be enough for the surgery.

Corneal clarity is essential for good vision after cataract surgery including phacoemulsification. It is maintained by corneal endothelial cells by their pumping action.
This pumping action maintains the corneal stroma in dehydrated state, thus assuring its transparency. This is an active process, accomplishing ion transport and corneal detergence via $\mathrm{Na}^{+} / \mathrm{K}^{+}$ATPase. ${ }^{1}$ The corneal endothelium is a complex structure with great variation in size, shape and interdigitation between adjacent cells, each of which can influence transparency. ${ }^{2}$ The endothelial cell density is about $6000 / \mathrm{mm}^{2}$ at birth and falls by $26 \%$ at the first year. A further $26 \%$ is lost over the next 11 years. Thereafter rate of loss slows and possibly stabilizes around middle age. ${ }^{3}$ To ensure corneal stromal detergence a minimum density of $400-500 / \mathrm{mm}^{2}$ is required to sustain the pumping activity of endothelium. Dysfunction results in corneal decompensation and loss of vision. ${ }^{4}$ So, morphological

1. Professor, Department of Ophthalmology, Ashiyan Medical College \& Hospital, Dhaka

Correspondence Md. Abdus Salam Siddique, Email: assiddique@yahoo.com. 
and numerical stability with functional integrity of corneal endothelium are essential for the long term maintenance of corneal clarity after cataract surgery. ${ }^{4}$

In phacoemulsification the cataract is broken into very small fragments by a high frequency ultrasonic probe and the fragments are then irrigated and aspirated. During the procedure corneal endothelium may be damaged by different ways, viz., mechanical injury caused by anterior chamber instrumentation - phaco tip, chopper, irrigation/aspiration canula and/or anterior chamber manipulation of hard lens nucleus, ultrasonic vibration of the phaco tip, heat generation and prolonged intraocular irrigation. ${ }^{5}$ Mechanical trauma is the main cause of endothelial cell loss. ${ }^{6}$ Similarly surge phenomenon may also cause damage to the corneal endothelium.

The present study was undertaken to ascertain the effect on endothelial cell count after phacoemulsification in patients at various time interval up to $1 \frac{1}{2}$ months after cataract surgery.

In Bangladesh perspective the rate of corneal endothelial decompensation after phacoemulsification, particularly in old age groups is not infrequent. The number of skilled phaco surgeons in our country is increasing gradually. The purpose of my study was to find out whether any significant endothelial cell loss happens during the phacoemulsification procedure that may lead to corneal endothelial decompensation.

\section{Materials and Methods}

This prospective study was conducted in National Institute of Ophthalmology \& Hospital (NIO\&H), Shere-Banglanagar, Dhaka during the period from July to September, 2008. In this study samples were selected purposively and conveniently from cataract patients attending outdoor of NIO\&H. Among them who fulfilled the inclusion criteria were selected for this study. Initially a total of 70 patients were included, among them 10 were excluded from final analysis due to failure to attend in follow-up examination. So, total 60 patients were finally included in the study for analysis.

Patients of both sexes of all social status from both urban and rural areas aged between 45-75 years were included in this study. Exclusion criteria were positive history of ocular trauma or intraocular surgery, corneal disease, uveitis and glaucoma and preoperative complications such as PC tear, vitreous loss etc.

The study parameters were endothelial cell count (preand postoperatively), measurement of VA (pre- and postoperatively) and measurement of intraocular pressure (IOP) (pre- and postoperatively).

Methodology of the current study included detailed history and clinical examination including general, systemic and ophthalmological examination. Then clinical and laboratory investigations were carried out to assess the fitness for surgery. Informed written consents were taken from all patients. Pre-operative measurements of parameters were taken. Complete blood count, glucose estimation (FBS, 2 hours PPBS), ECG, SPT, IOP measurement, biometry and specular microscopy were done for all study subjects and chest radiography $\mathrm{P} / \mathrm{A}$ view in some cases.

Cataract extraction by phacoemulsification through clear corneal incision with PCIOL implantation was done using both rigid PMMA and foldable lenses. All operations were done by same surgeon and also same type of viscoelastic substances and similar irrigation fluid were used in all cases. Patients were followed-up on $1^{\text {st }}$ POD, $7^{\text {th }}$ POD and after $1 \frac{1}{2}$ months after surgery. VA, SL examination, specular microscopy and IOP measurement before and after operation on follow-up dates by applanation tonometry were done routinely in all cases. Visual acuity seen by Snellen's charts was later converted to $\log$ MAR unit for statistical analysis.

All eyes underwent non-contact specular microscopy (Topton SP-2000P). At least four times the central corneal endothelial cells were calculated and recorded. In the same manner postoperative follow-up examinations were done. While taking the endothelial cell count, central cornea was focused first. Then the key of the joystick was clicked. A magnified view of endothelium of central cornea was obtained. Ten cells were selected from a box showing these cells. Finally in this state when the joystick was clicked again, the machine showed the number of endothelial cells which was expressed in the value of cells $/ \mathrm{mm}^{2}$.

History and clinical findings were collected in predesigned structured proforma for case study. Statistical analyses were done by using computer software. Cell loss was expressed as a percentage of the preoperative cell density. Paired Student t-test was done to determine 
significance of difference in the study group. A probability value of equal to or less than 0.05 was considered significant. Scatter diagram was drawn to see the correlation between endothelial cell losses at different follow-up periods.

\section{Results}

Out of 60 patients finally included in this study 24 (40\%) were within the age group 45-59 years and 36 $(60 \%)$ were in $60-75$ years group. Mean age was $63 \pm$ 6.23 years. Table I shows the distribution of study subjects according to age.

Table I: Distribution of the study subjects according to age $(n=60)$

\begin{tabular}{|c|c|c|c|}
\hline $\begin{array}{c}\text { Age groups } \\
\text { (in years) }\end{array}$ & Number & Percentage & Mean \pm SD \\
\hline $49-59$ & 24 & 40 & $\begin{array}{c}63 \pm 6.23 \\
\text { years }\end{array}$ \\
\hline $60-75$ & 36 & 60 & \\
\hline
\end{tabular}

Table II shows the distribution of preoperative endothelial cell count of the study patients. Twenty four patients in the age group 45-59 years had mean preoperative endothelial cell count of $2975.35 \pm$ 368.86 and 36 patients in $60-75$ years group had mean preoperative endothelial cell count of $2415.43 \pm$ 217.10.

Table II: Preoperative endothelial cell count in different age groups

\begin{tabular}{|c|c|c|}
\hline $\begin{array}{c}\text { Age groups } \\
\text { (in years) }\end{array}$ & Number & $\begin{array}{c}\text { Mean pre-operative } \\
\text { endothelial cell count }\end{array}$ \\
\hline $45-59$ & 24 & $2975.35 \pm 368.86($ SD) \\
\hline $60-75$ & 36 & $2415.43 \pm 217.10($ SD) \\
\hline
\end{tabular}

Table III and Fig 1 show the visual acuity expressed in $\log$ MAR unit among the study patients. Preoperative mean value of visual acuity expressed in logMAR unit was 1.38. After phacoemulsification mean visual acuity was recorded as $0.27,0.15$ and 0.08 during follow-up at $1^{\text {st }}$ POD, 1 week and $1 \frac{1}{2}$ months respectively.
Table III: Visual acuity expressed in logMAR unit among the study subjects $(n=60)$

\begin{tabular}{|c|c|}
\hline $\begin{array}{c}\text { Period of measurement } \\
\text { of visual acuity }\end{array}$ & $\begin{array}{c}\text { Mean value } \\
\text { of logMAR }\end{array}$ \\
\hline Pre-operative & 1.38 \\
\hline $1^{\text {st }}$ POD & 0.27 \\
\hline After 1 week & 0.15 \\
\hline After $1 \frac{1}{2}$ months & 0.08 \\
\hline
\end{tabular}

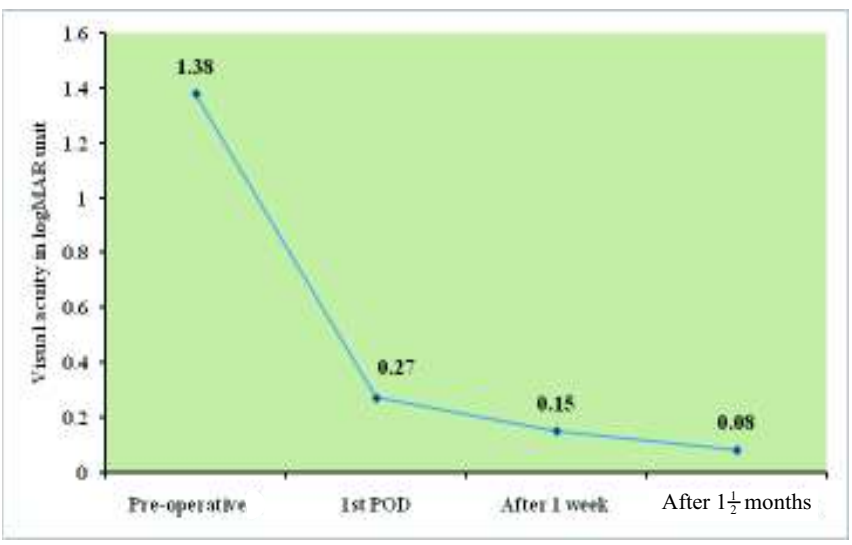

Fig 1. Line graph showing visual acuity expressed in $\log$ MAR unit among the study subjects in different period

Table IV and Fig 2 show the distribution of endothelial cell density expressed in number $/ \mathrm{mm}^{2}$ among the study subjects. Pre-operative endothelial cell density was $2745.35 \pm 395.27$ (SD). After phacoemulsification, endothelial cell density was found $2585.07 \pm 355.65$ (SD), $2564.72 \pm 347.23$ (SD) and $2545.23 \pm 348.83(\mathrm{SD})$ cells $/ \mathrm{mm}^{2}$ respectively at follow-up on $1^{\text {st }} \mathrm{POD}, 1$ week and $1 \frac{1}{2}$ months after surgery.

Table IV: Endothelial cell density among the study subjects at different intervals of follow-up $(\mathrm{n}=60)$

\begin{tabular}{|c|c|}
\hline $\begin{array}{c}\text { Period of measurement of } \\
\text { endothelial cell density }\end{array}$ & $\begin{array}{c}\text { Cells } / \mathrm{mm}^{2} \\
(\text { Mean } \pm \text { SD) }\end{array}$ \\
\hline Pre-operative & $2745.35 \pm 395.27$ \\
\hline $1^{\text {st }}$ POD & $2585.07 \pm 355.65$ \\
\hline After 1 week & $2564.72 \pm 347.23$ \\
\hline After $1 \frac{1}{2}$ months & $2545.23 \pm 348.83$ \\
\hline
\end{tabular}




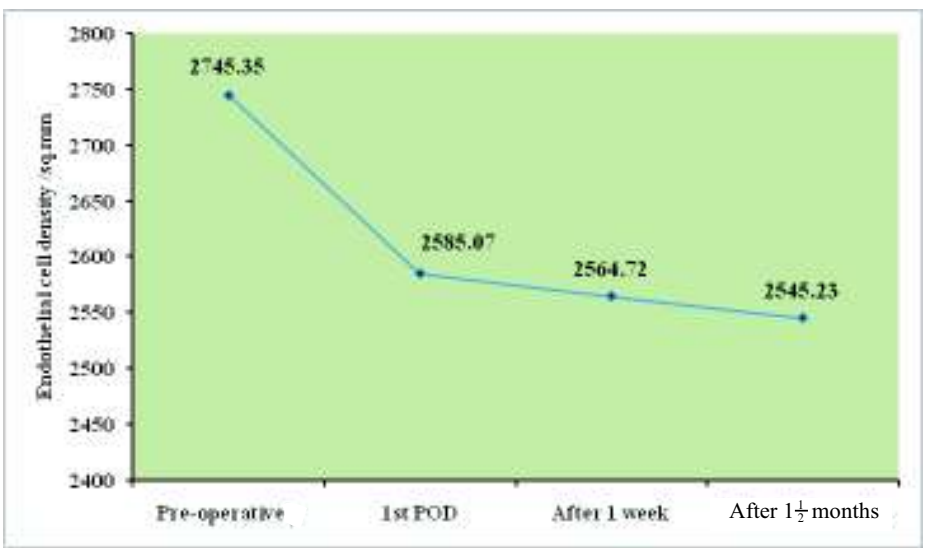

Fig 2. Line graph showing endothelial cell density $/ \mathrm{mm}^{2}$ among the study subjects

Table V shows mean cell loss between preoperative value and different periods of follow-up. The mean cell loss values are $160.28 \pm 39.62(5.84 \%), 180.63 \pm 48.08(6.58 \%)$ and $200.12 \pm$ $46.44(7.29 \%)$ at follow-up on $1^{\text {st }}$ POD, at 1 week and $1 \frac{1}{2}$ months after surgery.

Table V: Mean cell loss at different periods of follow-up compared with preoperative values

\begin{tabular}{|l|c|c|c|}
\hline Follow-up periods & $\begin{array}{c}\text { Mean endothelial cell loss } \\
\text { Number/mm² }(\text { Mean } \pm \text { SD) }\end{array}$ & $\begin{array}{c}\text { Percentage of } \\
\text { cell loss }\end{array}$ & P values \\
\hline Preoperative to $1^{\text {st }}$ POD & $160.28 \pm 39.62$ & 5.84 & $<0.001 * * *$ \\
\hline Preoperative to 1 week & $180.63 \pm 48.08$ & 6.58 & $<0.001 * * *$ \\
\hline Preoperative to $1 \frac{1}{2}$ months & $200.12 \pm 46.44$ & 7.29 & $<0.001 * * *$ \\
\hline
\end{tabular}

*** Highly significant. Done by paired t-test.

\section{Discussion}

Corneal transparency is of vital importance for the visual function of eye. Maintenance of corneal transparency is one of the main physiological functions of the corneal endothelium. Endothelial pump function maintains this. So, integrity of the endothelial cells and their junctions is important. A compromise in either cell loss or metabolic functional change without reduction of cell number may lead to corneal complication related to transparency. Corneal edema is a frequent complication of intraocular surgery.

Ocular surgery including the cataract extraction is the main cause for the reduction of endothelial cell count. It was reported that no further post-operative endothelial cell loss occurs after 15 weeks of follow-up in ECCE with PCIOL. ${ }^{7}$ Another study also reveals that endothelial cell density stabilizes and morphological change resolves within three months in all regions of the cornea. ${ }^{2}$ Central endothelial cell density is stabilized approximately 3 months after uncomplicated intraocular surgery and a little change occurs thereafter. ${ }^{8}$ Although those study periods do not correlate exactly with the time period $\left(1 \frac{1}{2}\right.$ months after surgery) of this study, but those findings still correlate well with that of the current study.

The types of cataract in this study were selected on random basis, but complicated, secondary and traumatic cataracts were excluded from the study. In this study, distribution of types of cataract was posterior subcapsular cataract 20 $(33.3 \%)$, cortical cataract $15(25 \%)$, nuclear cataract $15(25 \%)$ and other types $10(16.7 \%)$ among the study patients.

Increased brunescence of cataract, increased phaco power and prolonged phaco time are associated with more cell loss. ${ }^{9}$ That is why nuclear grading of cataract of each patient was recorded and considered in demographic variables and was similarized to overcome bias in outcome measures. In this current study the distribution of nuclear grading of cataract among patients showed that the proportion of Grade III cataract was the highest $(24,40 \%)$ and Grade I cataract was the lowest $(6,10 \%)$. Grade II cataract was $20(33.3 \%)$ and Grade V was 10 $(16.7 \%)$.

Visual acuity was recorded by Snellen's acuity chart and converted to $\log$ MAR unit. In the current study pre-operative visual acuity expressed in $\log$ MAR unit was 1.38. After phacoemulsification mean visual acuity was recorded as $0.27,0.15$ and 0.08 at the follow-up on $1^{\text {st }}$ POD, 1 week and $1 \frac{1}{2}$ months after surgery respectively. From the above descriptions it is seen that there was rapid visual recovery just after 1 day of operation which gradually improved up to $1 \frac{1}{2}$ months.

In the current study mean pre-operative endothelial cell density was $2745.35 \pm 395.27$ $(\mathrm{SD}) / \mathrm{mm}^{2}$. In the study of Inoue et al ${ }^{10}$ preoperative cell density was found $2543 \pm 254$ cells $/ \mathrm{mm}^{2}$. In the study of Kohlas et al ${ }^{11}$ this value was $2640 \pm 340$. These findings nearly correlate with the findings of current study. 
In our study mean cell loss between pre-operative value and different periods of follow-up are $160.28 \pm 39.62$ $(5.84 \%), 180.63 \pm 48.04(6.58 \%)$ and $200.12 \pm 46.44$ $(7.29 \%)$ at the first POD, 1 week and $1 \frac{1}{2}$ months after surgery. In another study, the cell loss was found $16 \%$ at the end of 3 months after phacoemulsification. ${ }^{4}$ Schultz et $\mathrm{al}^{2}$ showed cell loss $15-16.7 \%$ in their study. DiazValle et $\mathrm{al}^{12}$ showed $11.8 \%$ cell loss after 3 months. In this study cell loss was $7.29 \%$ at the end of $1 \frac{1}{2}$ months which is less than the above studies. Improved technology in phaco machine, improved design of intraocular lens materials, improved skill in surgical procedure and proper patient selection may be the causes of less endothelial cell damage in the current study. Kohlas et $\mathrm{al}^{11}$ reported no further postoperative loss of endothelial cells after 4 weeks, which suggest that wound healing is complete by this time.

The visco-elastic substances such as sodium hyaluronate, hydroxypropyl methyl cellulose and chondrointin sulphate protect corneal endothelium. Visco-elastics have the potential complication of rise of intraocular pressure (IOP), which may be up to a dangerous level. In a study it was found that the aqueous outflow facility was decreased up to $65 \%$ due to viscoelastic. ${ }^{13}$ Hydroxypropyl methyl cellulose is less expensive than other visco-elastic substances currently available. It has been proven very simple to use. In the present study hydroxypropyl methyl cellulose $(2 \%)$ was used as visco-elastic in all cases. A rise of intraocular pressure, occurring at 12 to 24 hours post-operative, may be prevented by meticulous washing it from the eye at the end of surgery. In the current study, the mean IOP was increased by a few $\mathrm{mm}$ of $\mathrm{Hg}$ on the $1^{\text {st }} \mathrm{POD}$, but came to the preoperative value on the next follow-up.

Other than visco-elastic substances and irrigation solutions some other drugs are also used in modern ophthalmology surgery. The effect of these drugs such as acetylecholine, pilocarpin and carbacol is of great importance. In this study population, no drugs except hydroxypropyl methyl cellulose and irrigation solution Ringers lactate and injection adrenaline mixed in it were used. Among the irrigating fluids, balanced salt solution (BSS) is widely used. On the other hand, Ringers solution has been in use for a long time for same purpose without detectable serious complication. In the current study, both PMMA and foldable IOLs were used though the significant numbers of cases were of the $1^{\text {st }}$ group, as these patients could not afford foldable IOLs which are relatively costly.

Corneal thickness measurements may serve as a parameter for assessing overall endothelial function in corneas with a diseased endothelium or with borderline low endothelial cell counts. But in the present study, this parameter was not included due to lack of logistic support. In order to evaluate the degree of surgical trauma and endothelial status, morphological criteria are more important. This is because the functional capacity of the endothelium is substantial and corneal cell depletion is not reflected in corneal thickness measurements until there has been substantial loss of corneal endothelial cells.

In this study, no patient suffered from endothelial decompensation because all the patients had good endothelial cell count preoperatively and single competent phaco surgeon operated all the cases. The age limit of the patients was 45-75 years in my study, which may be an important factor for good cell count. So, at this age group preoperative endothelial cell count is not mandatory for these cases.

The study concludes that moderate endothelial cell loss after phacoemulsification may happen but it does not necessarily hamper corneal transparency and visual function if the cell count is above the physiological threshold.

\section{Limitations of the study}

Limitations of the current study include the relatively small number of sample, short follow-up period and avoidance of endothelial morphology and corneal thickness study. Short follow-up was due to decreased compliances factor and endothelial morphology study was avoided due to machine factor. Corneal thickness could not be measured due to lack of logistic support.

\section{References}

1. Hart WM. The Cornea. In: Hart WM (ed). Adler's physiology of the eye - clinical application. $9^{\text {th }}$ edn. Missouri: MosbyYear Book, Inc., 1992: 29.

2. Shultz RO, Glasser DB, Matsuda M, Yee RW, Edelhauser HF. Response of the corneal endothelium to cataract surgery. Arch Ophthalmol 1986; 104(1): 164-169.

3. The cornea. In: Bron AJ, Tripathi RC, Tripathi BJ (eds). Wolff's anatomy of the eye and orbit. $8^{\text {th }}$ edn. London: Chapman and Hall, 1997: 233-267. 
4. Ventura ACS, Walti R, Bohnke M. Corneal thickness and endothelial density before and after cataract surgery. Br J Ophthalmol 2001; 85:18-20.

5. Binder P, Sternberg H, Wickman M, Worthen D. Corneal endothelial damage associated with phacoemulsification. Am J Ophthalmol 1976; 82: 48-54.

6. Bourne WM, Kaufman HE. Specular microscopy of human corneal endothelium in vivo. Am J Ophthalmol 1976; 81: 319-326.

7. Bourne WM, Nelson LR, Hodge D. Central corneal endothelial cell changer over a ten-year period. Ophthalmol Vis-Sci 1997; 38(3): 779-782.

8. Nanako F, Seiji H, Yukari Y. Corneal endothelial change after posterior chamber intraocular lens implantation in patients with or without diabetes mellitus. Br J Ophthalmol 1990; 74 : 258-296.
9. Hayashi K, Hayashi H, Nakao F, Hayashi F. Risk factors for corneal endothelial injury during phacoemulsification. J Cataract Refract Surgery 1996; 22: 1079-1084.

10. Inoue K, Takuda Y, Inoue Y, Amano S, Oshika T, Inoue J. Corneal endothelial cell morphology in patients undergoing cataract surgery. Cornea 2002; 21(4): 360-363.

11. Kohlas M, Stahlhut O, Tholuck J, Richard G. Changes in the corneal thickness and endothelial cell density after cataract extraction using phacoemulsification. Ophthalmology 1997; 94: 515-518.

12. Diaz-Valle D, Benitez D, Castillo JM, Castillo A, Sayagues O, Moriche M. Endothelial damage with cataract surgery techniques. J Cataract Refract Surg 1998; 24(7): 951-955.

13. Berson FG, Patterson MM, Epstein DL. Obstruction of aqueous outflow by sodium hyaluronate in enucleated human eyes. Am J Ophthalmol 1983; 95: 668-672. 